
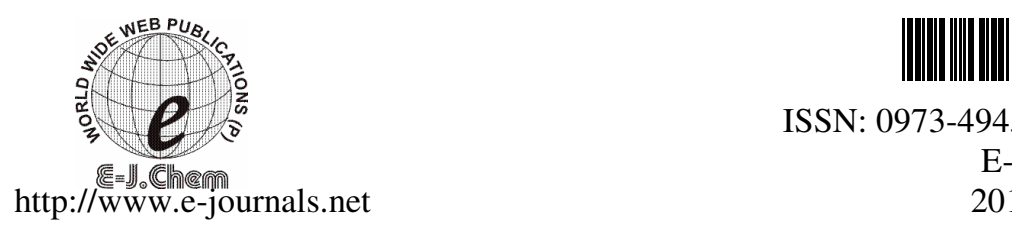

ISSN: 0973-4945; CODEN ECJHAO

E-Journal of Chemistry

2010, 7(S1), S391-S399

\title{
Kinetics and Mechanism of Oxidation of Hexamethylenediaminetetraacetatocobaltate(II) Complex by Periodate Ion in Aqueous Medium
}

\author{
R. M. NAIK*, B. KUMAR J.RAI, R.RASTOGI and S. B. S. YADAV \\ Department of Chemistry \\ University of Lucknow, Lucknow - 226 007, India \\ naik_rm2003@yahoo.com
}

Received 7 January 2009; Accepted 12 April 2009

\begin{abstract}
The kinetics and mechanism of oxidation of $\left[\mathrm{Co}^{\mathrm{II}} \mathrm{HDTA}\right]^{4-}$ (Where HDTA=Hexamethylenediamine tetraacetic acid $\}$ by periodate ion has been studied in aqueous acidic medium. The reactions has been investigated spectrophotometrically at $\lambda_{\max }=580 \mathrm{~nm}$ under pseudo- first -order condition by taking large excess of oxidant $\left[\mathrm{IO}_{4}\right]$ at $\mathrm{pH}=4.0 \pm 0.02, \mathrm{I}=0.1 \mathrm{M}\left(\mathrm{CH}_{3} \mathrm{COONa}+\right.$ $\mathrm{NaNO}_{3}$ ) and temperature $=30 \pm 0.1{ }^{\circ} \mathrm{C}$ The electron transfer reaction between $\left[\mathrm{Co}^{\mathrm{II}} \mathrm{HDTA}\right]^{4-}$ and $\left[\mathrm{IO}_{4}^{-}\right]$obeys inner sphere reaction pathway through the formation of long-lived intermediate complex which finally get converted into a corresponding $\left[\mathrm{Co}^{\text {III }} \mathrm{HDTA}\right]^{3-}$ complex as final reaction product. The experimental observations have shown that the reaction obey first- order dependence in $\left[\mathrm{Co}^{\mathrm{II}} \mathrm{HDTA}\right]^{4-}$. The variation of pseudo-first-order rate constants $\left(\mathrm{k}_{\mathrm{obs}}\right)$ with $\left[\mathrm{IO}_{4}^{-}\right]$, keeping other reaction variables fixed at constant value was found to obey the rate law: $\mathrm{k}_{\mathrm{obs}}=\mathrm{a}\left[\mathrm{IO}_{4}{ }^{-}\right] 2 / \mathrm{b}+\mathrm{c}\left[\mathrm{IO}_{4}^{-}\right]$, which is consistent with a three step mechanistic scheme. The values of $\mathrm{k}_{\mathrm{obs}}$ are almost constant with increasing $\mathrm{pH}$, which can be attributed to the reaction of deprotonated form of $\left[\mathrm{Co}^{\mathrm{II}} \text { HDTA }\right]^{4-}$ complex only, in the entire $\mathrm{pH}$ region. Eyring's equation has been used to calculate the thermal or activation parameters and found to be, $\Delta \mathrm{H}^{\#}=28.69 \mathrm{~kJ} \mathrm{~mole}^{-1} ; \Delta \mathrm{S}^{\#}=-481.13 \mathrm{~J} \mathrm{~K}^{-1}$ mole $^{-1}$ respectively and support the proposed mechanistic scheme.
\end{abstract}

Keywords: Kinetics and Mechanism, Electron transfer reactions, Hexamethylenediaminetetraacetatocobaltate(II), Periodate.

\section{Introduction}

Sodium meta periodate $\left[\mathrm{IO}_{4}^{-}\right]$has been used for the oxidation of vast variety of inorganic ${ }^{1-4}$ and organic ${ }^{5-6}$ substrates. The periodate oxidation of $\left[\mathrm{Co}^{\mathrm{II}} \mathrm{L}\left(\mathrm{H}_{2} \mathrm{O}\right)\right]^{2-\mathrm{n}}(\mathrm{L}=\mathrm{EDTA}$, HEDTA, 
NTA, DTPA, PDTA and HPDTA) complexes have been the subject of interest for several investigators in the past and recently ${ }^{7}$. The detailed kinetic and spectroscopic studies on periodate oxidation of these complexes suggests that the electron transfer takes place through the formation of inner sphere complexes of type $\left[\mathrm{LCo}^{\mathrm{II}}-\mathrm{OIO}_{3}\right]^{1-\mathrm{n}}$ and $\left[\mathrm{LCo}^{\mathrm{II}}-\left(\mathrm{OIO}_{3}\right)_{2}\right]^{-\mathrm{n}}$ which eventually get converted slowly producing $\left[\mathrm{Co}^{\mathrm{III}} \mathrm{L}\left(\mathrm{H}_{2} \mathrm{O}\right)\right]^{3-\mathrm{n}}$ as final reaction product. The periodate oxidation of $\mathrm{V}(\mathrm{IV})^{2}, \mathrm{Fe}(\mathrm{II})^{4}$ and $\mathrm{Cr}(\mathrm{III})^{8}$ complexes are also found to proceed via an inner sphere electron transfer pathway. The recent studies on the oxidation of $\left[\mathrm{Co}{ }^{\mathrm{II}} \mathrm{L}\left(\mathrm{H}_{2} \mathrm{O}\right)\right]^{2-\mathrm{n}}$ $[\mathrm{L}=\text { HEDTA and EDTA }]^{9-10}$ by vandate ion $\left(\mathrm{VO}_{2}{ }^{+}\right)$too have showed the formation of an intermediate which is slowly converted to penta coordinated $\left[\mathrm{Co}^{\mathrm{III}} \mathrm{L}\left(\mathrm{H}_{2} \mathrm{O}\right)\right]^{3-\mathrm{n}}$ as final reaction product, which also supports the proposed mechanism.

The oxidation of cobalt(II) complexes by $\left[\mathrm{IO}_{4}^{-}\right]$appears to proceed by two parallel pathways, the first obeying first-order kinetics in each reactant and the other first order in cobalt(II) complexe and second order in oxidant concentration. The pathway which is first order in each reactant concentration, almost certainly proceed via an inner sphere electron transfer process and lends further support to the proposed mechanistic scheme for the reaction at hand.

In the present study, an attempt have been made to verify the consistency in kinetics and mechanism of oxidation of $\left[\mathrm{Co}^{\mathrm{II}} \mathrm{L}\left(\mathrm{H}_{2} \mathrm{O}\right)\right]^{2-\mathrm{n}}$ ( $\mathrm{L}=$ Hexamethylenediamine tetraacetic acid (HDTA)) by periodate ion in acidic buffer medium to assess the reactivity of periodate ion with relatively more stable complex of $\mathrm{Co}(\mathrm{II})$ with HDTA.

\section{Experimental}

Double distilled water was used to prepare all the solutions throughout the present study. Since polyaminocarboxylates are sparingly soluble in water, accordingly a small amount of dil. sodium hydroxide was added to prepare stock solution of ligand viz. HDTA (Aldrich) by weighing its calculated amounts. Fresh solution of sodium meta periodate (S.d Fine-Chem Limited) was prepared and wrapped with aluminium foil to avoid photochemical decomposition ${ }^{11}$. Sodium acetate (Merck) and sodium nitrate (Sigma) were prepared by weighing their calculated amounts. The standard solution of acetic acid was prepared by titrating it against sodium hydroxide using phenolphthalein as an indicator.

The progress of reaction was monitored spectrophotometrically using a single beam visible spectrophotometer DIGI-110 (SISCO, India) equipped with thermostated cell compartment. A Shimadzu double beam spectrophotometer model UV-240 was used for recording UV-visible spectrum of reactants and products as well as the repetitive spectral scans of the reaction mixture as a function of time under specified experimental conditions. The $\mathrm{pH}$ of the reaction mixtures were checked on a Toshniwal digital $\mathrm{pH}$ meter. The $\mathrm{pH}$ meter was standardized regularly using standard BDH buffers of $\mathrm{pH}=4.0$ and 7.0.

\section{Kinetic measurements}

The solution of $\left[\mathrm{Co}^{\mathrm{II}} \text { HDTA }\left(\mathrm{H}_{2} \mathrm{O}\right)\right]^{2-}$ was prepared by dissolving $10 \%$ excess of ligand viz. HDTA over cobalt nitrate solution, in order to ensure the complete complexation. The excess ligand also reduces the possibility to catalyse the periodate ion oxidations by any trace metal ions such as $\mathrm{Cu}(\mathrm{II})^{12}$ and $\mathrm{Mn}(\mathrm{II})^{13}$ present as impurities. The $\mathrm{Co}(\mathrm{II})$ complexes were prepared immediately before each kinetic run to avoid the possibility of any air oxidation of $\mathrm{Co}(\mathrm{II})$ complexes $^{14-16}$. The kinetics of oxidation of $\left[\mathrm{Co}^{\mathrm{II}} \mathrm{L}\left(\mathrm{H}_{2} \mathrm{O}\right)\right]^{2-\mathrm{n}}$ complex was studied in $\mathrm{pH}$ range 3.0-5.0 where no significant air oxidation of cobalt(II) complex was noticed. 
The temperature of reactants were maintained at $30 \pm 0.1^{\circ} \mathrm{C}$ by hanging them for at least half an hour in a thermostat and subsequently mixed in a sequence $\left[\mathrm{Co}{ }^{\mathrm{II}} \mathrm{L}\left(\mathrm{H}_{2} \mathrm{O}\right)\right]^{2-\mathrm{n}}$, buffer and sodium meta-periodate. The reaction mixture was shaken properly and transferred immediately to a cuvette of spectrophotometer having $10 \mathrm{~mm}$ path length. The temperature of the cuvette compartment too was maintained at $30 \pm 0.1^{\circ} \mathrm{C}$ by a circulatory water arrangement from thermostat. The reaction was found to proceed in forward direction with an increase in absorbance at $580 \mathrm{~nm}$, where $\left[\mathrm{Co}{ }^{\mathrm{II}} \mathrm{L}\left(\mathrm{H}_{2} \mathrm{O}\right)\right]^{2-\mathrm{n}}$ complex and $\left[\mathrm{IO}_{4}^{-}\right]$have negligible absorptions. The values of pseudo-first order-rate constant $\left(\mathrm{k}_{\mathrm{obs}}\right)$ were evaluated from the slopes of $\log \left(\mathrm{A}_{\infty}-\mathrm{A}_{\mathrm{t}}\right)$ versus time plots, where $A_{t}$ and $A_{\infty}$ are the absorbances at any time ' $t$ ' and at infinite time respectively.

\section{Results and Discussion}

\section{The effect of $\left[\mathrm{IO}_{4}^{-}\right]$on oxidation of $\left[\mathrm{Co}^{\mathrm{II}} \mathrm{HDTA}\left(\mathrm{H}_{2} \mathrm{O}\right)\right]^{2-}$}

The rate of reaction for oxidation of $\left[\mathrm{Co}^{\mathrm{II}} \mathrm{HDTA}\left(\mathrm{H}_{2} \mathrm{O}\right)\right]^{2-}$ by periodate ion has been studied under pseudo-first-order condition by taking sufficiently large excess of $\left[\mathrm{IO}_{4}^{-}\right]$over [Co ${ }^{\mathrm{II}}$ $\left.\mathrm{L}\left(\mathrm{H}_{2} \mathrm{O}\right)\right]^{2-}$ complex. The progress of reaction was monitored spectrophotometrically at 580 nm with an increase in absorbance at $\mathrm{pH}=4.0 \pm 0.02, \mathrm{I}=0.1\left(\mathrm{CH}_{3} \mathrm{COONa}+\mathrm{NaNO}_{3}\right)$ and at temperature $=30 \pm 0.1{ }^{\circ} \mathrm{C}$.

The plot of $\log \left(\mathrm{A}_{\infty}-\mathrm{A}_{\mathrm{t}}\right)$ versus time yields a straight line. The values of pseudo-firstorder rate constants $\left(k_{\text {obs }}\right)$ were determined from the slopes of such plots. The values of $k_{\text {obs }}$ was found to increase with increase in the entire range of periodate ion concentration chosen for the present investigation. The plots of $\mathrm{k}_{\mathrm{obs}}$ versus $\left[\mathrm{IO}_{4}^{-}\right]$yield straight line evidenced from the Figure 1. The plot of $\mathrm{k}_{\text {obs }} /\left[\mathrm{IO}_{4}^{-}\right]$versus $\left[\mathrm{IO}_{4}^{-}\right]$is also linear as shown in Figure 2. The linear plot of $\mathrm{k}_{\mathrm{obs}} /\left[\mathrm{IO}_{4}^{-}\right]$versus $\left[\mathrm{IO}_{4}^{-}\right]$can be described by the following empirical equation.

$$
\frac{k_{o b s}}{\left[\mathrm{IO}_{4}^{-}\right]}=k_{2}+k_{3}\left[\mathrm{IO}_{4}^{-}\right]
$$

The eq.(1) is in good conformity with the equation of a straight line. The values of $\mathrm{k}_{2}$ and $\mathrm{k}_{3}$ can be obtained from the intercepts and the slopes of the linear plots given in Figure 2. The values of $\mathrm{k}_{2}$ and $\mathrm{k}_{3}$ are found to be $2.66 \times 10^{-2} \mathrm{M}^{-1} \mathrm{sec}^{-1}, 6.6 \times 10^{-2} \mathrm{M}^{-2} \mathrm{sec}^{-1}$ for $\left[\mathrm{Co}^{\mathrm{II}} \text { HDTA }\left(\mathrm{H}_{2} \mathrm{O}\right)\right]^{2-}-\left[\mathrm{IO}_{4}^{-}\right]$system. It is interesting to note that the value of $\mathrm{k}_{2}$ obtained from the intercepts of the plots given in Figure 2 is in excellent agreement with the slopes $\left(\mathrm{k}_{\mathrm{f}}\right)$ calculated from the plots of Figure 1. The mathematical basis of eq.(1) will be presented on the basis of proposed mechanistic scheme for the reactions at hand (vide supra).

\section{The effect of complex variation on periodate oxidation of $\left[\mathrm{Co}^{\mathrm{II}} \mathrm{HDTA}\left(\mathrm{H}_{2} \mathrm{O}\right)\right]^{2-}$}

Keeping all experimental parameters constant at $\mathrm{pH}=4.0 \pm 0.02, \mathrm{I}=0.1 \mathrm{M}\left(\mathrm{CH}_{3} \mathrm{COONa}+\right.$ $\left.\mathrm{NaNO}_{3}\right),\left[\mathrm{IO}_{4}^{-}\right]=2.0 \times 10^{-2} \mathrm{M}$ and temp $=30 \pm 0.1{ }^{\circ} \mathrm{C}$ for $\left[\mathrm{Co}^{\mathrm{II}} \mathrm{HDTA}\left(\mathrm{H}_{2} \mathrm{O}\right)\right]^{2-}-\left[\mathrm{IO}_{4}^{-}\right]$, the dependence of rate on $\left[\mathrm{Co}^{\mathrm{II}} \mathrm{L}\left(\mathrm{H}_{2} \mathrm{O}\right)\right]^{2-}$ was found to be invariant with in the chosen concentration range (Table 1$)$. The values of $\mathrm{k}_{\mathrm{f}}\left(\mathrm{k}_{\mathrm{obs}} /\left[\mathrm{IO}_{4}^{-}\right]\right)$also do not depend on the concentration of $\left[\mathrm{Co}^{\mathrm{II}} \mathrm{HDTA}\left(\mathrm{H}_{2} \mathrm{O}\right)\right]^{2-}$.

The effect of $\mathrm{pH}$ on the rate of oxidation of $\left[\mathrm{Co}^{\mathrm{II}} \mathrm{HDTA}\left(\mathrm{H}_{2} \mathrm{O}\right)\right]^{2-}$

The rate of oxidation of $\left[\mathrm{Co}^{\mathrm{II}} \mathrm{HDTA}\left(\mathrm{H}_{2} \mathrm{O}\right)\right]^{2-}$ by periodate ion has been followed as a function of $\left[\mathrm{H}^{+}\right]$concentration in the $\mathrm{pH}$ range 3.42-4.99 and 3.00-4.27 respectively, keeping all other reaction variables constant at the same time. The values 
of $\mathrm{k}_{\mathrm{obs}}$ and $\mathrm{k}_{\mathrm{f}}$ at different $\mathrm{pH}$ values are compiled in Table 2 for $\left[\mathrm{Co}^{\mathrm{II}} \mathrm{HDTA}\left(\mathrm{H}_{2} \mathrm{O}\right)\right]^{2-}$ $\left[\mathrm{IO}_{4}^{-}\right]$and show that it is fairly constant with increasing $\mathrm{pH}$ of reaction medium in the system. The constancy in rate constant with increasing $\left[\mathrm{OH}^{-}\right]$concentration suggest that the only unprotonated forms of $\left[\mathrm{Co}^{\mathrm{II}} \mathrm{L}\left(\mathrm{H}_{2} \mathrm{O}\right)\right]^{2-\mathrm{n}}$ complex as well as periodate ion are the major reactive species in the entire chosen $\mathrm{pH}$ region.

Table 1. Effect of $\left[\mathrm{Co}^{\mathrm{II}} \mathrm{HDTA}\left(\mathrm{H}_{2} \mathrm{O}\right)\right]^{2-}$ on its reaction with $\left[\mathrm{IO}_{4}^{-}\right],\left[\mathrm{IO}_{4}\right]=2.0 \times 10^{-2} \mathrm{M}$, $\mathrm{pH}=4.0 \pm 0.02$, Temperature $=30 \pm 0.1{ }^{\circ} \mathrm{C}$ and $\mathrm{I}=0.1 \mathrm{M}\left(\mathrm{CH}_{3} \mathrm{COONa}+\mathrm{NaNO}_{3}\right)$

\begin{tabular}{ccc}
\hline$\left[\mathrm{Co}^{\text {II }} \mathrm{HDTA}\left(\mathrm{H}_{2} \mathrm{O}\right)\right]^{2-} \times 10^{3} \mathrm{M}$ & $\mathrm{k}_{\mathrm{obs}} \times 10^{4} \mathrm{sec}^{-1}$ & $\mathrm{k}_{\mathrm{f}} \times 10^{1} \mathrm{M}^{-1} \mathrm{sec}^{-1}$ \\
\hline 1.00 & 5.41 & 0.271 \\
1.13 & 5.45 & 0.273 \\
1.25 & 5.39 & 0.268 \\
1.50 & 5.47 & 0.273 \\
1.70 & 5.43 & 0.272 \\
2.00 & 5.38 & 0.266 \\
& $\mathrm{k}_{\text {obs }}(\mathrm{av})=5.42 \pm 0.03$ & $\mathrm{k}_{\mathrm{f}}(\mathrm{av})=0.271 \pm 0.02$ \\
\hline
\end{tabular}

Table 2. Effect of $\mathrm{pH}$ on the reaction of $\left[\mathrm{Co}^{\mathrm{II}} \mathrm{HDTA}\left(\mathrm{H}_{2} \mathrm{O}\right)\right]^{2-}$ with $\left[\mathrm{IO}_{4}^{-}\right] \quad\left[\mathrm{Co}^{\mathrm{II}} \mathrm{HDTA}\right.$ $\left.\left(\mathrm{H}_{2} \mathrm{O}\right)\right]^{2-}=1.13 \times 10^{-3} \mathrm{M},\left[\mathrm{IO}_{4}\right]=2.0 \times 10^{-2} \mathrm{M}$ Temperature $=30 \pm 0.1{ }^{\circ} \mathrm{C}$ and $\mathrm{I}=0.1 \mathrm{M}$ $\left(\mathrm{NaNO}_{3}+\mathrm{CH}_{3} \mathrm{COONa}\right)$

\begin{tabular}{cccc}
\hline $\mathrm{pH}$ & {$\left[\mathrm{H}^{+}\right] \times 10^{4}$} & $\mathrm{k}_{\mathrm{obs}} \times 10^{4} \mathrm{sec}^{-1}$ & $\mathrm{k}_{\mathrm{f}} \times 10^{1} \mathrm{M}^{-1} \mathrm{sec}^{-1}$ \\
\hline 3.42 & 3.80 & 5.69 & 0.285 \\
3.72 & 1.91 & 5.62 & 0.281 \\
4.27 & 0.54 & 5.64 & 0.282 \\
4.63 & 0.23 & 5.62 & 0.281 \\
4.99 & 0.10 & 5.65 & 0.282 \\
\cline { 3 - 4 } & & $\mathrm{k}_{\text {obs }}(\mathrm{av})=5.64 \pm 0.01$ & $\mathrm{k}_{\mathrm{f}}(\mathrm{av})=0.287 \pm 0.03$ \\
\hline
\end{tabular}

The effect of ionic strength on the rate of oxidation of $\left[\mathrm{Co}^{\mathrm{II}} \mathrm{HDTA}\left(\mathrm{H}_{2} \mathrm{O}\right)\right]^{2-}$

The dependence of rate on ionic strength for the oxidation of $\left[\mathrm{Co}^{\mathrm{II}} \mathrm{HDTA}\left(\mathrm{H}_{2} \mathrm{O}\right)\right]^{2-}$ by periodate ion have been investigated in the range of $\mathrm{I}=0.05-0.275$ and $\mathrm{I}=0.05-0.25$ respectively keeping all the variables constant at the same time. The values of $k_{\text {obs }}$ and $\mathrm{k}_{\mathrm{f}}$ as a function of ionic strength are listed in Table 3. The values of $\mathrm{k}_{\mathrm{f}}$ are found to be almost constant with increasing ionic strength of medium. This constancy in values of $k_{f}$ or $k_{o b s}$ with ionic strength may be either due to $\mathrm{k}_{2}$ or $\mathrm{k}_{3}$ or both (vide supra).

Table 3. Effect of ionic strength on the reaction of $\left[\mathrm{Co}^{\mathrm{II}} \mathrm{HDTA}\left(\mathrm{H}_{2} \mathrm{O}\right)\right]^{2-}$ with $\left[\mathrm{IO}_{4}\right]$ $\left[\mathrm{Co}^{\mathrm{II}} \mathrm{HDTA}\left(\mathrm{H}_{2} \mathrm{O}\right)\right]^{2-}=1.13 \times 10^{-3} \mathrm{M},\left[\mathrm{IO}_{4}\right]=2.0 \times 10^{-2} \mathrm{M}$, Temperature $=30 \pm 0.1{ }^{\circ} \mathrm{C}$ and $\mathrm{pH}$ $=4.0 \pm 0.02$

\begin{tabular}{ccc}
\hline $\mathrm{I}(\mathrm{M})$ & $\mathrm{k}_{\mathrm{obs}} \times 10^{4} \mathrm{sec}^{-1}$ & $\mathrm{k}_{\mathrm{f}} \times 10^{1} \mathrm{M}^{-1} \mathrm{sec}^{-1}$ \\
\hline 0.050 & 5.45 & 0.273 \\
0.100 & 5.45 & 0.272 \\
0.250 & 5.46 & 0.273 \\
0.275 & 5.48 & 0.274 \\
\cline { 2 - 3 } & $\mathrm{k}_{\text {obs }}(\mathrm{av})=5.46 \pm 0.01$ & $\mathrm{k}_{\mathrm{f}}(\mathrm{av})=0.273 \pm 0.02$ \\
\hline
\end{tabular}


The rate determining step for these reactions involves only one ionic species viz. $\left[\mathrm{LCo}^{\mathrm{II}}-\mathrm{OIO}_{3}\right]^{1-\mathrm{n}}$ or $\left[\mathrm{LCo}^{\mathrm{II}}\left(\mathrm{OIO}_{3}\right)_{2}\right]^{-\mathrm{n}}$ and there is no second ionic species reacting in these steps. This lends further support for the almost constant value of rate constant with increasing ionic strength.

The effect of temperature on oxidation of $\left[\mathrm{Co}^{\mathrm{II}} \mathrm{L}\left(\mathrm{H}_{2} \mathrm{O}\right)\right]^{2-n}$ by $\left[\mathrm{IO}_{4}^{-}\right]$

The influence of temperature on oxidation of both $\left[\mathrm{Co}^{\mathrm{II}} \mathrm{HDTA}\left(\mathrm{H}_{2} \mathrm{O}\right)\right]^{2-}$ by periodate ion have been studied in the temperature range $\mathrm{T}=298-323^{\circ} \mathrm{K}$. Activation parameters have been calculated by plotting $\ln \left(\mathrm{k}_{\mathrm{f}} / \mathrm{T}\right)$ versus $(1 / \mathrm{T})$ using Eyring's equation (2).

$$
\frac{k_{f}}{T}=\left(\frac{k_{B}}{h} \cdot e^{\Delta S^{\#} / R}\right) \cdot e^{-\Delta H^{\#} / R T}
$$

Where all the terms have their usual meanings. The values of evaluated activation parameters are compiled in Table 4 . The negative value of entropy of activation $\left(\Delta S^{\#}\right)$ suggests that reaction proceed via on associative $\left(\mathrm{S}_{\mathrm{N}}{ }^{2}\right)$ pathway through an inner sphere electron transfer.

Table 4. Activation Parameters for reaction

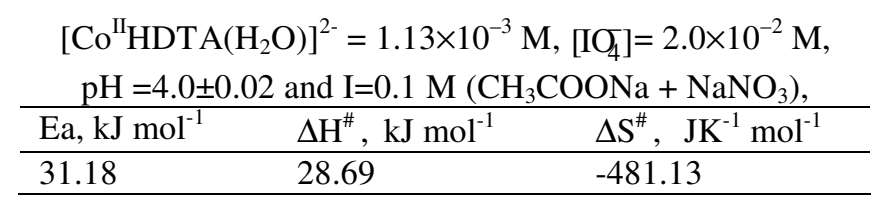

The mechanism of oxidation of $\left[\mathrm{Co}^{\mathrm{II}} \mathrm{HDTA}\left(\mathrm{H}_{2} \mathrm{O}\right)\right]^{2-}$ by periodate ion seems to proceed via an inner sphere electron transfer pathway in which an intermediate $\mathrm{Co}$ (III) complex be formed which finally yields the desired product. The oxidation of $\left[\mathrm{Co}^{\mathrm{II}} \mathrm{L}\left(\mathrm{H}_{2} \mathrm{O}\right)\right]^{2-}$ to $\left[\mathrm{Co}{ }^{\mathrm{III}} \mathrm{L}\left(\mathrm{H}_{2} \mathrm{O}\right)\right]^{1-}$ by periodate ion is thermodynamically favorable because the stability

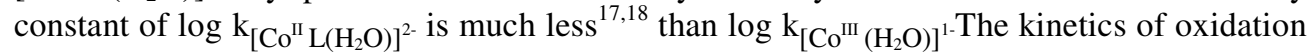
of the complex by periodate ion proceed by two parallel pathways. The first path exhibits first order dependence in each reactant. The second path exhibits first-order dependence in $\left[\mathrm{Co}{ }^{\mathrm{II}} \mathrm{L}\left(\mathrm{H}_{2} \mathrm{O}\right)\right]^{2-\mathrm{n}}$ complex and second order dependence in periodate concentration.

The experimental observations on the system at hand enabled us to propose the following mechanistic scheme through eqs. (3)-(6) in confirmation with our earlier proposed $^{7}$ mechanistic scheme proposed for periodate oxidations of $\left[\mathrm{Co}^{\mathrm{II}} \mathrm{L}\left(\mathrm{H}_{2} \mathrm{O}\right)\right]^{2-}$ complexes (L=PDTA and HPDTA).

$$
\begin{aligned}
& {\left[L \mathrm{Co}^{\mathrm{II}}\right]^{2-n}+\left[\mathrm{IO}_{4}^{-}\right] \stackrel{k_{1}}{\rightleftharpoons} \quad\left[\mathrm{LCo}^{\mathrm{II}-\mathrm{OIO}_{3}}\right]^{\mathrm{I}-\mathrm{n}}}
\end{aligned}
$$

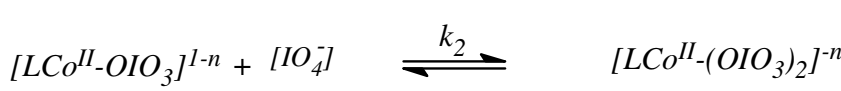

$$
\begin{aligned}
& {\left[\mathrm{LCo}^{\mathrm{II}}-\mathrm{OIO}_{3}\right]^{\mathrm{I-n}} \stackrel{k_{\mathrm{l}}^{e t}}{\longrightarrow} \quad\left[\mathrm{LCo}^{\mathrm{III}}-\mathrm{OIO}_{3}\right]^{\mathrm{I-n}}} \\
& {\left[\mathrm{LCo}^{\mathrm{II}}-\left(\mathrm{OIO}_{3}\right)_{2}\right]^{-n} \stackrel{k_{2}{ }^{e t}}{\longrightarrow} \quad\left[\mathrm{LCo}^{\mathrm{III}}\left(\mathrm{OIO}_{3}\right)_{2}\right]^{-n}}
\end{aligned}
$$

Where $\mathrm{L}=$ HDTA and $(-\mathrm{n})$ is the charge on each ligand. The general rate law which is consistent with above proposed mechanism can be given as:

$$
\text { Rate } \left.=k_{f}\left[\mathrm{Co}^{I I} \mathrm{~L}^{2-n}\right]_{\left[\mathrm{IO}_{4}^{-}\right.}\right]
$$


Since periodate ion is present in larger excess over $\left[\mathrm{Co}{ }^{\mathrm{II}} \mathrm{L}\left(\mathrm{H}_{2} \mathrm{O}\right)\right]^{2-}$ complex. Thus eq.(7) is further reduced to eq.(8).

Where $k_{o b s}=k_{f}\left[I_{4}^{-}\right]$

$$
\text { Rate }=k_{\text {obs }}\left[\mathrm{Co}^{I I} L^{2-n}\right]
$$

Eq. (8) is valid for the first pathway only, if eq.(5) in proposed mechanism is considered as rate determining step. Then,

$$
\text { Rate }=k_{l}^{e t}\left[\mathrm{LCo}^{\mathrm{II}}-\mathrm{OIO}_{3}\right]^{1-n}
$$

The eq.(10) is further reduced to eq.(11) with the help of eq.(3).

$$
\text { Rate }=k_{1} k_{l}^{e t}\left[\mathrm{Co}^{I I} \mathrm{~L}^{2-n}\right]\left[\mathrm{IO}_{4}^{-}\right]
$$

Comparison of eq.(7) and eq.(11) gives:

$$
k_{f}=k_{l} k_{l}^{e t}
$$

The graph plotted between $\mathrm{k}_{\mathrm{obs}}$ versus $\left[\mathrm{IO}_{4}^{-}\right]$shown in Figure 1 and Figure 2 have a slope which is found to be equal to $\mathrm{k}_{1} \mathrm{k}_{1}{ }^{\text {et }}=\mathrm{k}_{\mathrm{f}}$. Hence, the experimental rate law for first pathway [eq. (7)] and the theoretical rate law for the same pathway [eq. (11)] are the same provided $\mathrm{k}_{\mathrm{f}}=\mathrm{k}_{1} \mathrm{k}_{1}{ }^{\text {et }}$.

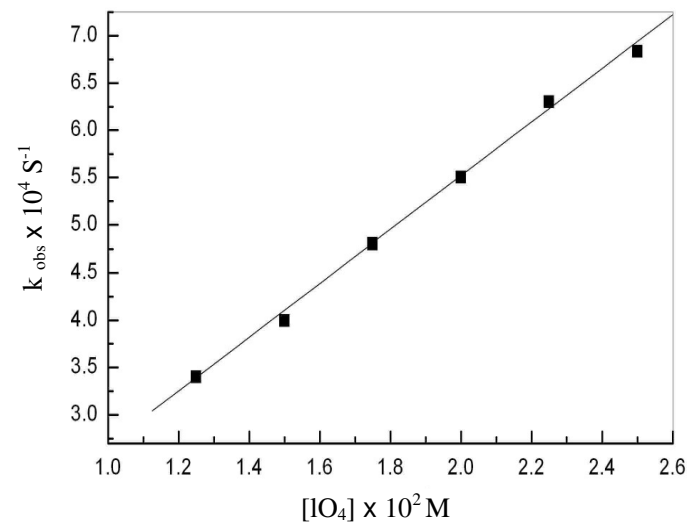

Figure 1. The periodate dependence of observed rate constant for $\left[\mathrm{Co}^{\mathrm{ll}} \mathrm{HDTQA}\left(\mathrm{H}_{2} \mathrm{O}\right)\right]^{2-}$ reaction system

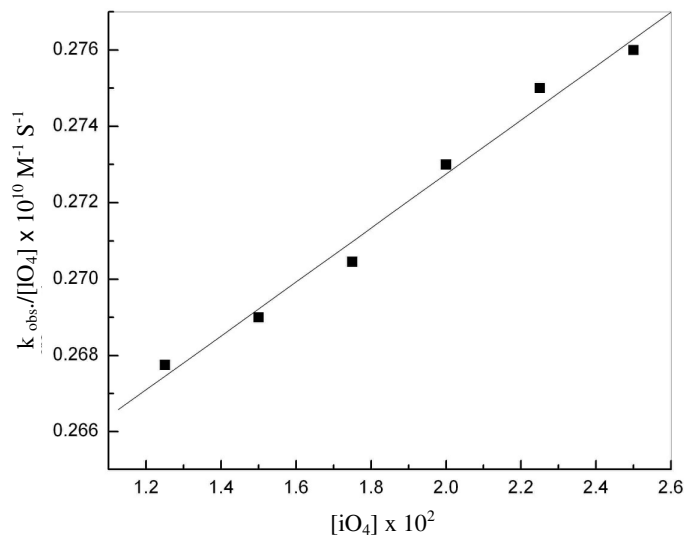

Figure 2. The periodate dependence of forward rate constant for $\left[\mathrm{Co}^{\mathrm{ll}} \mathrm{HDTA}\left(\mathrm{H}_{2} \mathrm{O}\right)\right]^{2-}$ reaction system 
Since, the periodate ion is present in large excess and second molecule of $\left[\mathrm{IO}_{4}\right]$ has a possibility to get added on $\left[\mathrm{LCo}^{\mathrm{II}}-\mathrm{OIO}_{3}\right]^{1-\mathrm{n}}$ to form $\left[\mathrm{LCo}^{\mathrm{II}}\left(\mathrm{OIO}_{3}\right)_{2}\right]^{-\mathrm{n}}$ as an intermediate. Thus, for the second pathway both the step (5) and (6) of proposed mechanism are to be considered simultaneously to be rate determining steps and the rate law is given by eq. (13).

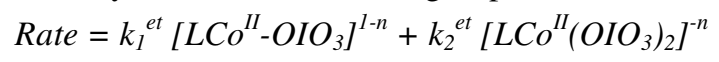

Eq.(13) can be further transformed to eq. (14) with the help of eqs. (3) and (4)

$$
\begin{gathered}
\text { Rate }=k_{1}{ }^{e t} k_{1}\left[\mathrm{Co}^{I I} L^{2-n}\right]\left[\mathrm{IO}_{4}^{-}\right]+k_{2}{ }^{e t} k_{1} k_{2}\left[\mathrm{Co}^{I I} L^{2-n}\right]\left[\mathrm{IO}_{4}^{-}\right]^{2} \\
\text { or } \\
\text { Rate }=\left\{k_{1}^{e t} k_{1}+k_{2}{ }^{e t} k_{1} k_{2}\left[\mathrm{IO}_{4}^{-}\right]\right\}\left[\mathrm{Co}^{I I} L^{2-n}\right]\left[\mathrm{IO}_{4}^{-}\right]
\end{gathered}
$$

Now on comparing eq.(14) with eq.(7), we get

$$
k_{f}=k_{l}^{e t} k_{1}+k_{2}^{e t} k_{l} k_{2}\left[I O_{4}^{-}\right]
$$

From eq. (14) and eq. (9), we get:

$$
\frac{k_{o b s}}{\left[I O_{4}^{-}\right]}=k_{1}^{e t} k_{1}+k_{2}^{e t} k_{1} k_{2}\left[I O_{4}^{-}\right]
$$

The theoretical rate law for the second path of reaction given by eq.(16) is in conformity with the empirical experimental rate law given by eq.(1) where $\mathrm{k}_{2}=\mathrm{k}_{1}{ }^{\text {et }} \mathrm{k}_{1}$ and $\mathrm{k}_{3}=\mathrm{k}_{1} \mathrm{k}_{2} \mathrm{k}_{2}{ }^{\mathrm{et}}$. It was earlier proposed that the oxidations by periodate ion generally proceed via an inner sphere mechanism ${ }^{1,3-5}$. Hence, the oxidation process involving second order dependence in $\left[\mathrm{IO}_{4}^{-}\right]$, probably also proceeds via an inner sphere electron transfer pathway. Formation of $\left[\mathrm{LCo}^{\mathrm{II}}-\left(\mathrm{OIO}_{3}\right)_{2}\right]^{-\mathrm{n}}$ takes place by the substitution of a water molecule by two periodate ions. During the formation of $\left[\mathrm{LCo}^{\mathrm{II}}\left(\mathrm{OIO}_{3}\right)_{2}\right]^{-\mathrm{n}}$ in $\left[\mathrm{CO}^{\mathrm{II}} \mathrm{HDTA}\left(\mathrm{H}_{2} \mathrm{O}\right)\right]^{2-}$ a carboxylate arm present in ligands gets free. A second order dependence in $\left[\mathrm{IO}_{4}^{-}\right]$was also reported in its reaction

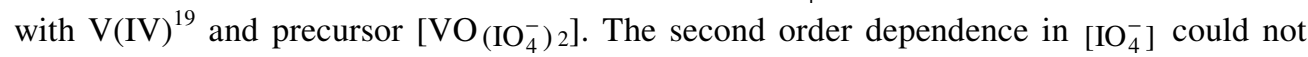
result from a dimerisation of periodate as this occurs at higher $\mathrm{pH}$ values ${ }^{20}$. The existence of initial $\mathrm{Co}(\mathrm{III})$ products in the systems under investigation render additional support in the favor of the above proposed mechanism.

The pseudo-first-order rate constant $\left(\mathrm{k}_{\mathrm{obs}}\right)$ and the forward rate constant $\left(\mathrm{k}_{\mathrm{f}}\right)$ for the oxidation of $\left[\mathrm{Co}^{\mathrm{II}} \mathrm{HDTA}\left(\mathrm{H}_{2} \mathrm{O}\right)\right]^{2-}$ by $\left[\mathrm{IO}_{4}\right]$ are found to be fairly constant as the $\mathrm{pH}$ of the reaction mixture increases (Table 2). This clearly indicates that the unprotonated forms of $\left[\mathrm{Co}{ }^{\mathrm{II}} \mathrm{HDTA}\left(\mathrm{H}_{2} \mathrm{O}\right)\right]^{2-}$ is the predominant reacting species with the periodate ion throughout the whole $\mathrm{pH}$ region under investigation. The structure of $\left[\mathrm{Co}^{\mathrm{II}} \mathrm{HDTA}\left(\mathrm{H}_{2} \mathrm{O}\right)\right]^{2-}$ is not known either in solution phase or in solid phase. However, the penta coordinated structure of $\mathrm{Ni}$ (II) with EDTA, PDTA and TMDTA has been determined by Evilia ${ }^{21}$ in aqueous medium. Since the structure of the complex under study is not known, we can not understand the reactivities of protonated and unprotonated forms of the complex. However, on the basis of protonation constant of the complex it can be inferred that the unprotonated forms of this complex is stable and its reaction with periodate ion is slower in comparison to their protonated counterparts. The similar conclusion was made by $\mathrm{Sulfab}^{22}$, on $\left[\mathrm{Co}^{\mathrm{II}} \mathrm{DTPA}\left(\mathrm{H}_{2} \mathrm{O}\right)\right]^{3-}-\left[\mathrm{IO}_{4}\right]$ system and by Mansour ${ }^{8}$ on $\left[\mathrm{Cr}^{\mathrm{III}} \mathrm{NTMP}\right]-\left[\mathrm{IO}_{4}\right]$ system. The NMR study reveals that the three nitrogen of deprotonated forms of DTPA are coordinated to Co(II). The proton addition decreases the number of coordinated nitrogen ${ }^{23}$. This conclusion is also in further agreement with $\left[\mathrm{Cu}^{\mathrm{II}} \mathrm{DTPA}\right]$ complexes proposed by Chabarek ${ }^{24}$. 
The pseudo-first-order rate constant $\left(\mathrm{k}_{\mathrm{obs}}\right)$ and forward rate constant $\left(\mathrm{k}_{\mathrm{f}}\right)$ are found to be invariant with increasing ionic strength of the medium (Table 3). The constancy in values of $\mathrm{k}_{\mathrm{obs}}$ and $\mathrm{k}_{\mathrm{f}}$ with increasing ionic strength is due to $\mathrm{k}_{2}$. Eqs.(5) and (6) of the proposed mechanism of oxidation of $\left[\mathrm{Co}{ }^{\mathrm{II}} \mathrm{L}\left(\mathrm{H}_{2} \mathrm{O}\right)\right]^{2-\mathrm{n}}$ by periodate ion are the slowest and hence treated as rate determining step. The $\left[\mathrm{LCo}^{\mathrm{II}}-\mathrm{OIO}_{3}\right]^{1-\mathrm{n}}$ and $\left[\mathrm{LCo}^{\mathrm{II}}\left(\mathrm{OIO}_{3}\right)_{2}\right]^{-\mathrm{n}}$ are only reacting species in eqs.(5) and (6) and there is no second ionic species reacting in these steps. Therefore, the values of $\mathrm{k}_{\mathrm{obs}}$ and $\mathrm{k}_{\mathrm{f}}$ are found to be fairly constant. The values of activation parameters for the system show that the reaction is probably exothermic in nature due to formation of $\left[\mathrm{LCo}^{\mathrm{II}}-\mathrm{OIO}_{3}\right]^{1-\mathrm{n}}$ in each case. We could not make any inference on the entry of second periodate ion in absence of any experimental data on activation parameters for second path of reaction. However, it is expected that this path will have relatively higher values of enthalpy of activation in each case and will be endothermic in nature.

Finally, the repetitive spectral scan of $\left[\mathrm{Co}^{\mathrm{II}} \mathrm{HDTA}\left(\mathrm{H}_{2} \mathrm{O}\right)\right]^{2-}-\left[\mathrm{IO}_{4}\right]$ reaction system Figure 3 reveals that there is a continuous increase in absorbance at $405 \mathrm{~nm}$ and $580 \mathrm{~nm}$. This increase in absorbance at $405 \mathrm{~nm}$ and $580 \mathrm{~nm}$ as function of time are attributed due to formation of a $\mathrm{Co}(\mathrm{III})$ intermediate. The absorbance at $405 \mathrm{~nm}$ and $580 \mathrm{~nm}$ were finally found to decrease after several hours of reaction. This suggests the conversion of Co(III) intermediate to other final products. The kinetics of conversion of this Co(III) intermediate was not studied in detailed. However, preliminary kinetic observations made on the conversion of $\mathrm{Co}$ (III) intermediate suggest that the rate of reaction is extremely slow. The final form of spectrum is almost identical to the spectra of $\left[\mathrm{Co}^{\mathrm{III}} \mathrm{HDTA}\left(\mathrm{H}_{2} \mathrm{O}\right)\right]^{1-}$ as shown in Figure 3 by dotted spectra, which is the final product of oxidation of $\left[\mathrm{Co}^{\mathrm{II}} \mathrm{HDTA}\left(\mathrm{H}_{2} \mathrm{O}\right)\right]^{2-}$ by periodate ion.

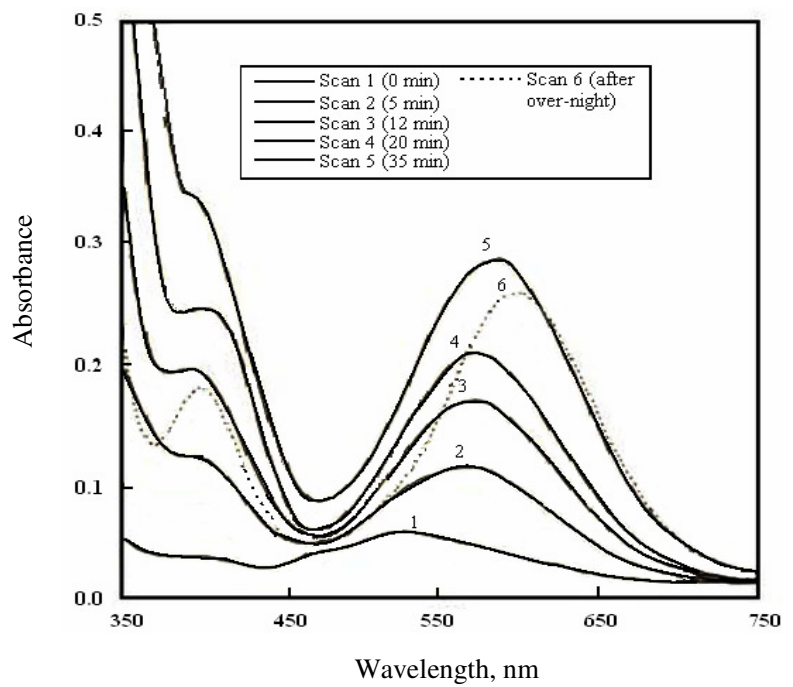

Figure 3. Spectral scan of the reaction mixture of $\left[\mathrm{Co}^{\mathrm{II}} \mathrm{HDTA}\left(\mathrm{H}_{2} \mathrm{O}\right)\right]^{2-}=1.25 \times 10^{-3} \mathrm{M}$, $\mathrm{pH}=4.0 \pm 0.02, \mathrm{I}=0.1 \mathrm{M}\left(\mathrm{CH}_{3} \mathrm{COONa}+\mathrm{NaNO}_{3}\right)$

\section{Conclusion}

Oxidation of hexamethylenediaminetetraacetatocobaltate(II) complex by periodate ion is unaffected by $\mathrm{pH}$ change in the entire chosen $\mathrm{pH}$ region. Oxidation of hexamethylenediamine tetraacetato cobaltate(II) complex yields the corresponding $\left[\mathrm{Co}^{\mathrm{III}} \text { HDTA }\right]^{3-}$ complex as final reaction product. Mechanistic step involved the electron transfer reaction between $\left[\mathrm{Co}^{\text {II }} \mathrm{HDTA}\right]^{4-}$ 
and $\left[\mathrm{IO}_{4}\right]$ obeys inner sphere reaction pathway through the formation of long-lived intermediate complex which finally get converted into product. The negative value of entropy adds additional support for the formation of the intermediate complex.

\section{References}

1. Sulfab Y J, Inorg Nucl Chem., 1976, 38(12), 2271-2274.

2. Sulfab Y and Abu-Shadi A.L, Inorg Chem Acta, 1977, 21, 115.

3. Kasim A.Y and Sulfab Y, Inorg Chem Acta, 1977, 24, 247.

4. El-Eziri F R and Sulfab Y, Inorg Chem Acta, 1977, 25, 15.

5. Buist G J, Comprehensive chemical kinetics edited by Boneford $\mathrm{C} \mathrm{H}$ and Tripper C F H, Elsevier, Amsterdam, 1972, 6, 435.

6. Indelli A, Ferranti F and Secco F, J Phys Chem., 1966, 70, 631.

7. Naik R M, Sarkar J, Chaturvedi D D, Singh S K and Verma A K, Indian J Chem., 2003, 42A, 1639.

8. Anis S S and Mansour M A, Trans Metal Chem., 2001, 26, 695.

9. Mansour M A, Trans Metal Chem., 2003, 28, 276.

10. Babu G R, Ramakrishna K, Venkateswarlu G and Subba Rao P V, Indian J Chem., 2003, 42A, 1053.

11. Head F S H and Standing H A, J Chem Soc., 1957, 1457.

12. Huchital D H and Hodges R J, Inorg Chem Acta, 1973, 12, 1004.

13. Mottala H A and Freiser H, Anal Chem, 1967, 39, 1294.

14. Kasim A Y and Sulfab Y, Inorg Chem Acta, 1977, 22, 169.

15. Norkus E, Vas Kelis A, Griguceviciene A, Rohovskrs G, Reklai H S J and Norkus P, Trans Metal Chem., 2001, 26, 465.

16. Naik R M, Srivastava A, Verma A K Yadav S B S, Singh R and Prasad S, Inorg React Mech., 2007, 6, 185.

17. Martell A E, Stability Constants of Metal ion Complexes, Alden Press Oxford, 1971, 53, 17.

18. Martell A E and Smith R M, Critical Stability Constants, Vol. 1, Amino acids, Plenum, New York, London, 1974, 283.

19. Galiford D J B and Ottaway J M, Analyst, 1972, 91, 415.

20. Buist B J, Hipperson W C P and Lewis J D, J Chem Soc A., 1969, 307.

21. Everhart D S and Evilia R F, Inorg Chem., 1975, 14, 2755-2759.

22. Sulfab Y, et al., Polyhedron, 1990, 9, 99.

23. Grazynski L L and Trzebiatowska B J, Coord Chem., 1980, 10, 159.

24. Chabarek S, Frost A E, Doran M A and Bicknell N J, J Inorg Nucl Chem., 1959, 11, 184. 


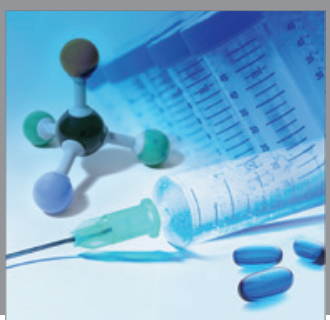

International Journal of

Medicinal Chemistry

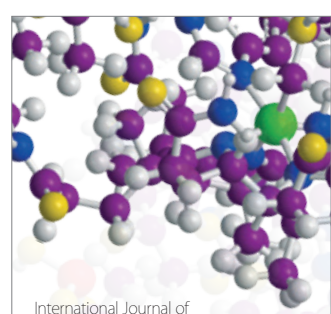

Carbohydrate Chemistry

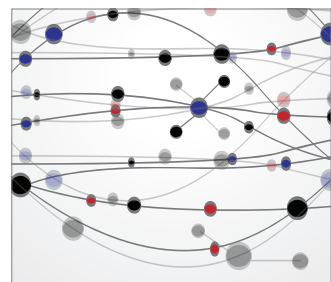

The Scientific World Journal
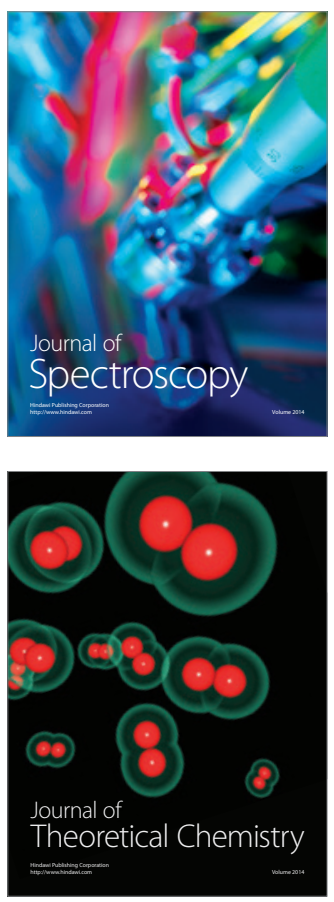
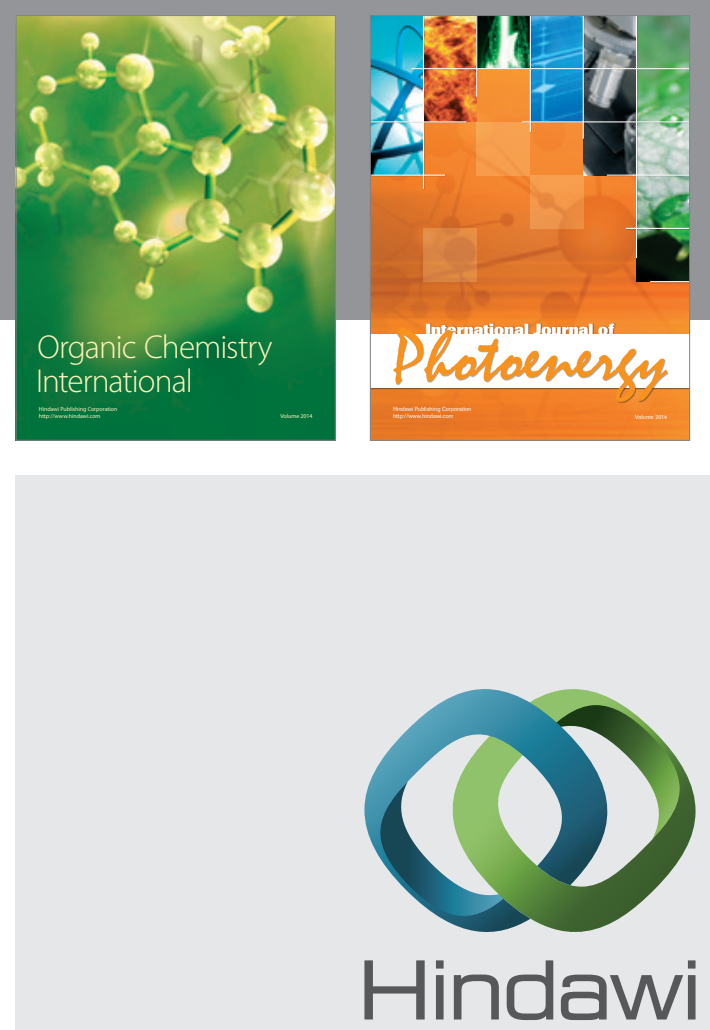

Submit your manuscripts at

http://www.hindawi.com
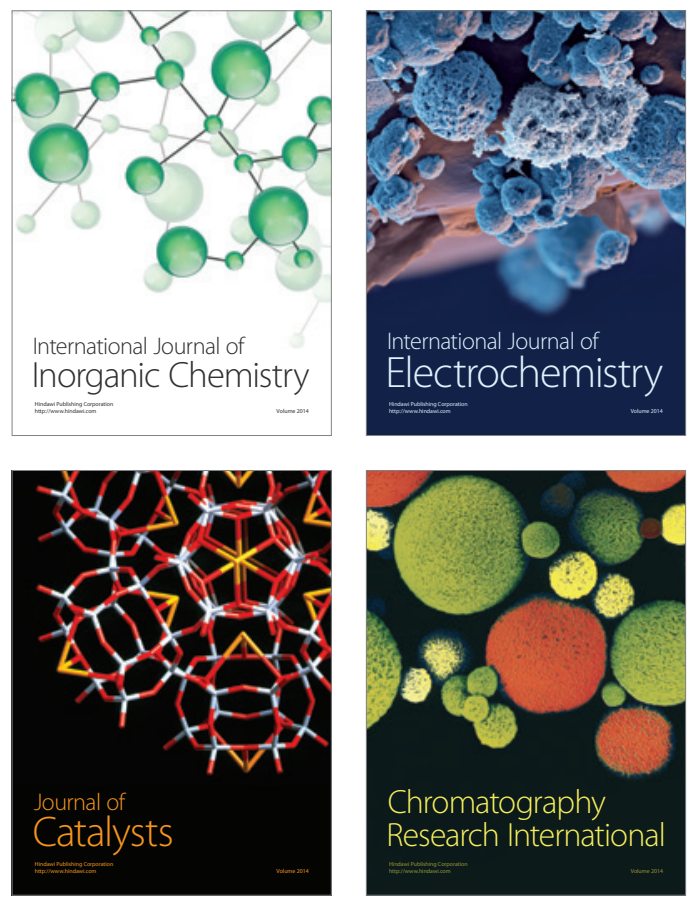
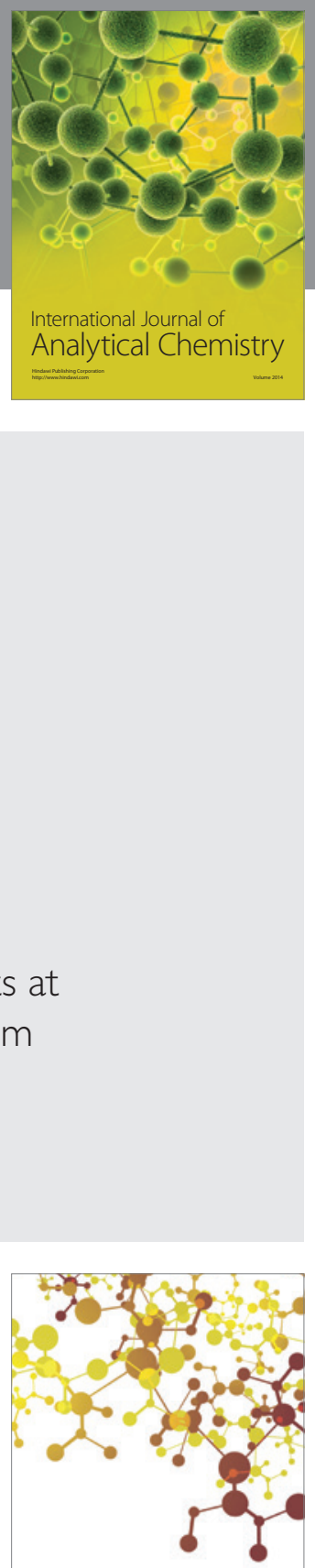

Journal of

Applied Chemistry
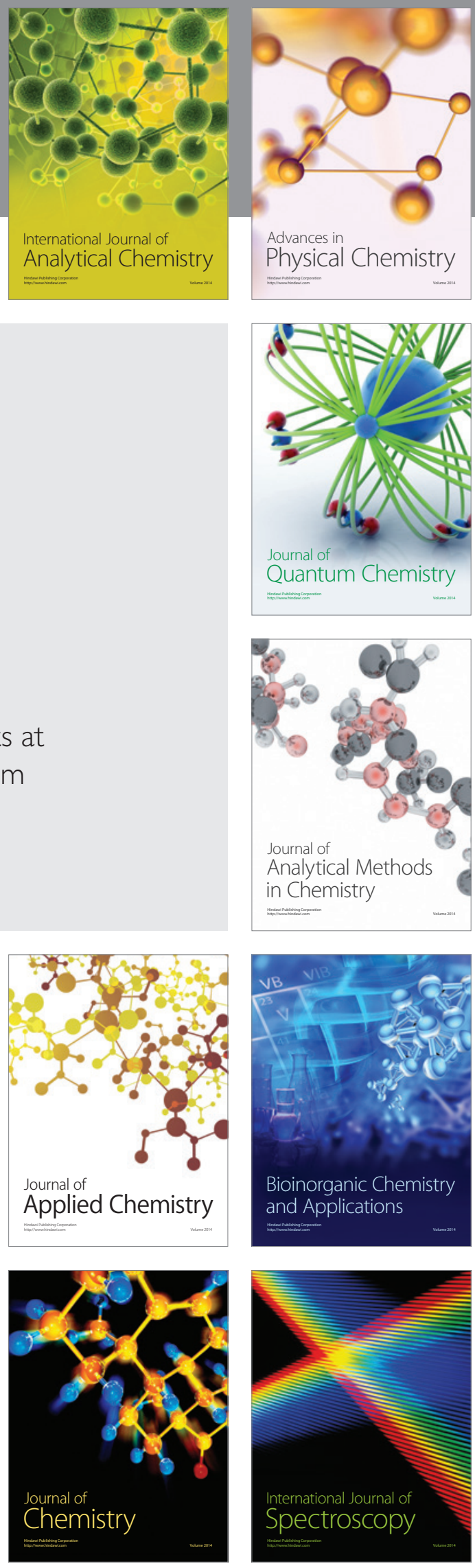